\title{
Risk Factors for Enzootic Leukosis in Dairy Cattle from the Brazilian Amazon*
}

\author{
Tamyres Izarelly Barbosa da Silva', Leonardo Augusto Kohara Melchior', Priscila Souza Santos', \\ Guilherme Henrique Reckziegel', Yuri Almeida Gomes', Artur Cesar Carvalho Fernandes'2, \\ Daniel Dias da Silva ${ }^{3}$, Luiz Carlos Fontes Baptista Filho ${ }^{3}$ \& Lúcio Esmeraldo Honório de Melo ${ }^{3}$
}

\begin{abstract}
Background: Enzootic bovine leukosis (EBL) is a viral and lymphoproliferative disease that attributes negative economic impacts to dairy farming. The immunosuppressive condition of these bovines favors the development of bacterial diseases such as tuberculosis, brucellosis, and bovine leptospirosis, which implications to the public health given that they are zoonosis. Diagnosis and control of EBL are neglected in cattle rearing, allowing their dissemination, especially in developing countries. In this sense, the objective of this study was to analyze the risk factors of EBL in dairy cattle from the Brazilian Amazon.

Materials, Methods \& Results: In order to identify the BLV-infected animals (527 serological samples), we used the agarose gel immunodiffusion serological test (IDGA) to diagnose the EBL and characterize the risk factors through the application of epidemiological questionnaires. We used the logistic regression test to evaluate the existence of a significant association between the variables. The EBL frequency in the study area was $14.42 \%$. We detected seroreagent bovines in all municipalities evaluated with $95 \%$ of the properties showing outbreaks of the disease. The reuse of needles was the risk factor with the most significant statistical association $(P<0.01$; OR $=2.16)$.

Discussion: The origin of EBL in the Brazilian Amazon is probably related to the expansion of dairy cattle in the 1980s, which, at first, demanded the importation of cattle for the fast formation of the herds, without complying with the sanitary criteria of animal commercialization. The frequency of EBL in the Rio Branco microregion is below the estimated national average, as well as the regional level. The reduced influx of animals due to the geographical situation of Acre, since it is an area of greater physical isolation due to forest and river barriers, may influence the observed frequency. Different environmental conditions, herd size, cattle management, genetics and particularities of the diagnostic techniques should also be considered. The Rio Branco microregion can currently be considered as an area of medium frequency for BLV infection, a situation that ranges from 11 to $30 \%$ in the occurrence rate. When compared to herds with low infection frequency $(<10 \%)$, the elimination of seroreagent animals and their respective outbreaks become more expensive in areas of medium or high frequency. As for the number of outbreaks detected, the finding reflects the degree of negligence regarding the prophylactic measures of EBL since it is a silent propagation disease, as well as the implications for the absence of official control and eradication programs in Brazil. According to the final logistic regression model, the reuse of needles for vaccinations, deworming, and for applying other drugs in different animals was the risk factor of greater association in the region, explaining the widespread occurrence of EBL in the studied farms. In Canadian herds, this practice also was associated with an increase in clinical cases. It is known that only $0.1 \mathrm{~mL}$ of blood is necessary as a minimal infectious dose of BLV. However, despite the relevance of this variable, it is little studied in epidemiological surveys, and this practice continues to be repeated in cattle. In conclusion, the wide dissemination of EBL in the dairy herds of the region is related to the practice of reusing needles and its relevance in the iatrogenic transmission of the disease.
\end{abstract}

Keywords: bovine leukosis virus, dairy cattle, epidemiological inquiry, logistic regression, Western Amazon.

*Article based on a Dissertation submitted by the senior author in partial fulfillment of requirements for the Doctor's Degree - Programa de Pós-graduação em Ciência Veterinária - UFRPE. 'Inidade de Ensino e Pesquisa em Medicina Veterinária, Universidade Federal do Acre (UFAC), Rio Branco, AC, Brazil. ${ }^{2}$ Universidade Federal da Paraíba (UFPB), Areia, PB, Brazil. ${ }^{3}$ Universidade Federal Rural de Pernambuco (UFRPE), Recife, PE, Brazil. CORRESPONDENCE: T.I.B. Silva [tamyres_ibs@ @otmail.com]. Rodovia BR 364, Km 04. Distrito Industrial. CEP 69920-900 Rio Branco, Acre, Brazil. 


\section{INTRODUCTION}

Enzootic bovine leukosis (EBL) is an infectious and chronic disease of great relevance to livestock production [18], caused by an oncogenic retrovirus denominated bovine leukosis virus (BLV) [10,32]. The transmission occurs through the hematogenous pathway and is associated to flaws in hygienicsanitary management of livestock, especially in an iatrogenic form, through the bite of hematophagous insect, or still by ingestion of fresh milk by neonates $[16,17,24,27,30,34]$. The World Organization for Animal Health recommends the mandatory notification of this disease and the slaughter of all infected animals [28].

The BLV is a B-lymphotropic microorganism that induces the formation of lymphosarcoma in approximately $2 \%$ of the infected cattle [25]. One-third of the animals may still manifest leukocytosis through the persistent lymphocytosis due to the disordered proliferation of $\mathrm{B}$ lymphocytes which become nonfunctional $[3,8,25]$. The immunosuppressive condition of these bovines favors the development of several bacterioses such as tuberculosis, brucellosis, and bovine leptospirosis [20,11], which attribute direct and indirect losses to herds, as well as implications to the public health given that they are zoonosis [29].

Diagnosis and control of EBL are neglected, allowing their dissemination, especially in developing countries $[32,40]$. In the Brazilian Amazon, prevalences ranging from $8.9 \%$ [6] to $49.8 \%$ [23]. However, the description of the epidemiological characteristics relevant to the transmission of EBL and its impacts on the herds it is not clarified. In this sense, the objective of this study was to analyze the risk factors of EBL in dairy cattle of the region.

\section{MATERIALS AND METHODS}

\section{Location of the study}

The state of the Acre is in the northwestern part of the country, in the southwest of the Amazon, has approximately 816,687 inhabitants, an area of 164,221.36 $\mathrm{km}^{2}$, and shares borders with Amazonas and Rondônia and international borders with Bolivia and Peru. The climate is equatorial, with temperatures ranging from 25 to $32^{\circ} \mathrm{C}$ and vegetation characteristic of the Amazon rainforest. The state is geographically divided in the mesoregion of the Juruá Valley, composed of the microregions of Cruzeiro do Sul and Tarauacá, and the mesoregion of the Acre Valley, composed of the microregions of Rio Branco, Sena Madureira, and Brasiléia [2].

According to estimates by the Instituto Brasileiro de Geografia e Estatística, there are 2,916,207 cattle in the state, 82,070 of which apt for dairy farming. The Rio Branco microregion (Figure 1), with $58.4 \%$ of this population, is the largest dairy production region in the state and the most populated, and was, thus, selected for the study. This microregion is formed by the municipalities of Rio Branco, the state capital, Acrelândia, Bujari, Capixaba, Plácido de Castro, Porto Acre, and Senador Guiomard [12].

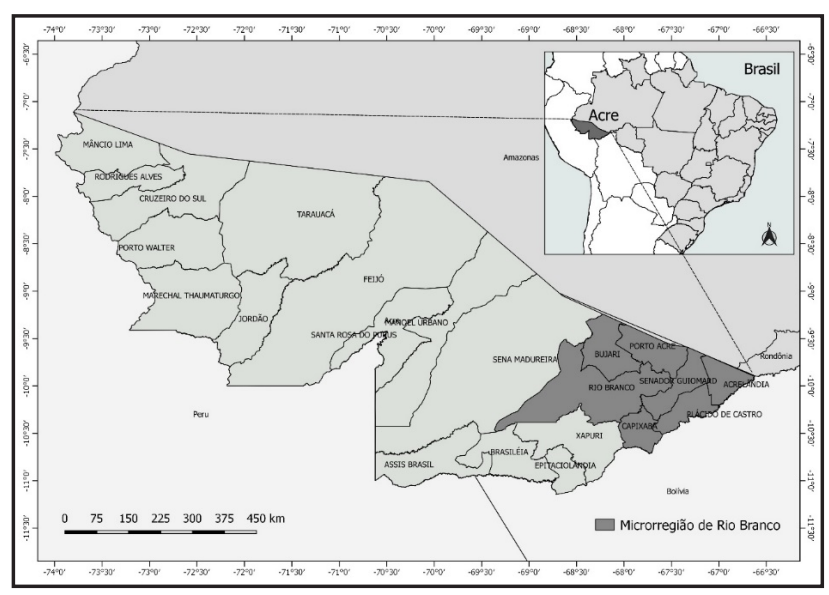

Figure 1. Geographical situation of the Rio Branco microregion, Acre, Brazilian Amazon.

\section{Sampling}

The sample population consisted of female and male dairy cattle, with ages over 24 months, reared under intensive or semi-intensive systems in the Rio Branco microregion, state of Acre, in the Brazilian Amazon. We selected the animals and their respective properties by non-probabilistic convenience. The sample size was established according to the criteria for detailed epidemiological surveys. We estimated a prevalence of $10 \%$ [1], with a $95 \%$ interval of confidence and a statistical error of 5\%, requiring at least 361 animals for the study [7]. However, it was possible to analyze 527 samples (513 females and 14 males), from 20 farms, of which we selected an average of 25 cattle per establishment.

\section{Serological diagnosis}

To identify the BLV-infected animals, we used the agarose gel immunodiffusion serological test (IDGA) to detect anti-BLV antibodies according to the 
protocol developed by Miller \& Van Der Maaten [21], also recommended by the OIE [28]. For this technique, we used the glycoprotein $51(\mathrm{gp} 51)^{1}$ as an antigen, licensed by the Ministério da Agricultura, Pecuária e Abastecimento (MAPA) under no. 7916/2001. The processing was performed in the Universidade Federal Rural de Pernambuco (UFRPE), Recife, Brazil.

\section{Risk factors}

To characterize the risk factors, we applied an epidemiological questionnaire with producers to obtain information on the structural characteristics of the facilities and the sanitary and reproductive management practices employed, totalizing 30 objective questions [24,28,37].

\section{Statistical analysis}

We submitted the results of the serological test per animal (dependent variable) and the risk factors evaluated (independent variables) to a bivariate exploratory analysis using Fisher's Exact method. As a working hypothesis (H1), we considered the existence of a significant association between variables at a significance level of 5\%. In this situation, we rejected the null hypothesis ( $\mathrm{H0}$ ), for which there would be no association. The values were described in p-value, odds ratio, the interval of confidence, and standard estimate error [7].

We applied the multiple logistic regression test for statistical modeling [7]. The final model was built by a gradual approach, observing the change in the Akaike information criterion (AIC) of each model, obtained with the minimum AIC and $P<0.05$, accord- ing to the formula: $\operatorname{Logit}(\mathrm{p})=\alpha+\beta 0+\beta 1 \mathrm{X} 1+\beta 2 \mathrm{X} 2$ $+\ldots+\beta \mathrm{nXn}+\mathrm{e}$, where $\mathrm{p}$ is the dependent variable (seropositivity); $\alpha$ is the intercept; $\beta 0$ is the constant; $\beta \mathrm{i}$ is the coefficient of regression; $\mathrm{Xi}$ are the independent variables (risk factors); and e is the error [37]. The analyses were performed using the R software (The R Foundation for Statistical Computing, New Zealand).

\section{RESULTS}

The EBL frequency in the Rio Branco microregion was $14.42 \%$ (76/527). Most of the positive animals were females $(97.4 \%$ - 74/76). We detected seroreagent cattle in all seven municipalities of the study area, and 95\% (19/20) of the properties were considered as an outbreak location. The infection rate in the municipalities and the individual farms ranged from 10 to $20.8 \%$ and 6.9 to $35 \%$, respectively.

According to the bivariate analysis of risk factors, there was a significant association $(P<0.05)$ for certain variables (Table 1). The reuse of needles, the presence of ectoparasites on the properties, reuse of palpation gloves, and absence of disinfection of perforating devices or instruments increased in between 1.90 and 2.16 times the probability of BLV infection. Regarding the age group, the prevalence of EBL was statistically higher from four to six years of age. None of the sampled properties practiced the quarantine for newly acquired animals or conducted a serological test to diagnose the EBL.

However, the only variable selected to elaborate the final statistical model through the logistic regression test was the reuse of needles, which represents the lowest value of AIC and the maximum significant association $(P<0.01)$ to the BLV infection (Table 2$)$.

Table 1. Risk factors associated with the enzootic bovine leukosis in the Rio Branco microregion, Acre, Brazilian Amazon.

\begin{tabular}{cccccc}
\hline Variable & Cases/Exposed & $P$ value & OR & IC $-95 \%$ & SE \\
\hline Reuse of needles & $50 / 262(19.1 \%)$ & $0.003^{\mathrm{a}}$ & 2.16 & $1.3-3.6$ & 0.56 \\
Presence of ectoparasites & $56 / 315(17.8 \%)$ & $0.008^{\mathrm{a}}$ & 2.07 & $1.2-3.6$ & 0.58 \\
Reuse of palpation gloves & $44 / 233(18.9 \%)$ & $0.010^{\mathrm{a}}$ & 1.90 & $1.2-3.1$ & 0.47 \\
Absence of disinfection & $45 / 240(18.8 \%)$ & $0.011^{\mathrm{b}}$ & 1.90 & $1.2-3.1$ & 0.48 \\
Age range (4 to 6 years) & $39 / 213(18.3 \%)$ & $0.026^{\mathrm{b}}$ & 1.75 & $1.1-2.9$ & 0.44 \\
Age range (superior to 6 years) & $02 / 05(40 \%)$ & 0.076 & 5.21 & $0.8-32.3$ & 4.85 \\
Rearing and confining system & $35 / 200(17.5 \%)$ & 0.117 & 1.47 & $0.9-2.4$ & 0.36 \\
Slaughter at the property & $11 / 61(18 \%)$ & 0.395 & 1.35 & $0.7-2.7$ & 0.49 \\
Inadequate facilities & $62 / 415(14.9 \%)$ & 0.515 & 1.22 & $0.7-2.3$ & 0.38 \\
Acquisition of new cattle & $48 / 320(15 \%)$ & 0.638 & 1.12 & $0.7-1.9$ & 0.28 \\
Reproduction through natural mounting & $55 / 373(14.7 \%)$ & 0.742 & 1.00 & $0.5-1.6$ & 0.25 \\
\hline
\end{tabular}

a Significant association at the level of 0.05 ; ' Significant association at the level of 0.01 ; OR= Odds ratio; IC - 95\%= Interval of confidence of $95 \%$; SE $=$ Standard estimation error. 
Table 2. Final model of the logistic regression for the risk factors associated to the enzootic bovine leukosis in the Rio Branco microregion, Acre, Brazilian Amazon.

\begin{tabular}{cccc}
\hline Variable & $P$ value & $\mathrm{Z}$ value & $\mathrm{SE}$ \\
\hline Intercept & 1.28 & -6.771 & -2.99 \\
Reuse of needles & $0.00287^{\mathrm{a}}$ & 2.982 & 0.77 \\
\hline
\end{tabular}

${ }^{\mathrm{a}}$ Significant association at the level of $0.01 ; \mathrm{SE}=$ Standard estimate error.

\section{DISCUSSION}

The origin of EBL in the Brazilian Amazon is probably related to the expansion of dairy cattle in the 1980s, which, at first, demanded the importation of cattle from the Midwest and Southeast of the country, for the fast formation of the herds, without complying with the sanitary criteria of animal commercialization. The acquisition of matrices and breeders from other states, such as Minas Gerais, Goiás, and São Paulo, places with high disease prevalence $[5,13,33]$ may have favored the circulation of BLV to different territories [9].

The frequency of EBL in the Rio Branco microregion $(14.42 \%)$ is below the estimated national average (33.9\%), as well as the regional level [31]. According to the latest epidemiological surveys of the northern states, seropositivity was $8.9 \%$ in Amazonas [6], 49.8\% in Pará [23], 23\% in Rondônia [22], and $27.8 \%$ in Tocantins [13]. The reduced influx of animals due to the geographical situation of Acre, since it is an area of greater physical isolation due to forest and river barriers, may influence the observed frequency.

The variation of EBL seroprevalence among Brazilian states is due to the different environmental conditions, herd size, cattle management, and genetics, as well as the particularities of the diagnostic techniques employed [14,24,37]. This scenario is also repeated in different countries [32] such as Mongolia [26], Iraq [14], China [39], and Japan [15,27], which reported varied prevalences of $3.9 \%, 7.75 \%, 18.3 \%$, and $66.8 \%$, respectively.

Growth in the occurrence of EBL occurs in relation to the study of Abreu et al. [1], who, when analyzing 1060 samples of bovine serum, determined a prevalence of $9.7 \%$ for the Acre state. According to the classification proposed by Shettigara et al. [38], the Rio Branco microregion can currently be considered as an area of medium frequency for BLV infection, a situation that ranges from 11 to $30 \%$ in the occurrence rate. When compared to herds with low infection frequency $(<10 \%)$, the elimination of seroreagent animals and their respective outbreaks become more expensive in areas of medium or high frequency [6].

Concerning the outbreaks, the percentage found $(95 \%$ - 19/20) was similar to that obtained in Maranhão (98.9\%) [36] and in Amazon region (100\%) [6] but discretely superior to other Brazilian surveys, ranging from 60 to $85 \%$ [13,23]. This finding reflects the degree of negligence regarding the prophylactic measures of EBL since it is a silent propagation disease, as well as the implications for the absence of official control and eradication programs in Brazil [28,35].

In a survey conducted in Acre state [1], the authors concluded that the importation of bovines from other states and confined rearing systems were the most favorable points to the dissemination of BLV in the Acre herds. However, in this study, there was no statistically significant difference for these characteristics, demonstrating that the other risk factors related to hygienic-sanitary management, especially iatrogenic transmission through the hematogenous pathway, would nowadays be more important in EBL epidemiology.

According to the final logistic regression model, the reuse of needles for vaccinations, deworming, and for applying other drugs in different animals was the risk factor of greater association in the Rio Branco microregion $(\mathrm{OR}=2.16, P<0.01)$, explaining the widespread occurrence of EBL in the studied farms. In Canadian herds, this practice was associated with an increase in clinical cases [24]. It is known that only $0.1 \mathrm{~mL}$ of blood is necessary as a minimal infectious dose of BLV. However, despite the relevance of this variable although this variable to spread the disease, it is little studied in epidemiological surveys, and this practice continues to be repeated in cattle [36].

The vector infestation $(\mathrm{OR}=2.07, P<0.01)$, favored by the inadequate management of manure, lack of parasitic control, and the Amazonian climate, allows the inoculation of infectious agents, such as BLV, during blood repast $[16,30,35]$. Rectal palpation for the diagnosis of gestation without changing gloves (OR = 
$1.90 ; P<0.01)$ is, in turn, a very common procedure in the farms, and allows the iatrogenic transmission of the virus through small excoriations in the rectum wall [24]. It can be stated that these variables should also be considered for controlling the EBL in Acre.

The occurrence of EBL is still related to the absence of disinfection of the facilities and fomites (OR $=1.90, P<0.05)$, especially drilling and sharp utensils used for marking or surgical procedures, due to the hematogenous vehiculation of BLV [14,24,35].

Regarding the age group, the chance of infection increased between four and six years of age (OR $=1.75, P<0.05)$, and is associated with the long period of viral incubation and the intensification of management (number of milking, rectal palpations, vaccinations, deworming, among others), which would increase the exposure to the agent $[10,14,17,37]$.

The compulsory notification and sanitary slaughter of all seroreagent animals can eliminate EBL from one region [32]. In high and medium-frequency areas [38], as in the state of Acre, it is economically more feasible to phase out the diseased animals by separating the healthy and diseased animals in lots, perform individualized management and replacement with seronegative cattle, and conduct preventive actions based on the risk factors indicated in this study [18,27]. Under these conditions, the incidence and prevalence of EBL tend to reduce [19]. However, in Brazil, no government program encourages the diagnosis, control, and prophylaxis of the disease, which makes tracking and eradication difficult and creates an alarming epidemiological situation for the health of the herds and the country's economy.

\section{CONCLUSION}

The EBL is widely disseminated in dairy cattle from the Brazilian Amazon, and its occurrence is mainly related to the practice of reusing needles, a risk factor with extreme relevance in the iatrogenic transmission of BLV. This study serves as an alert to the health authorities for the implementation of diagnosis, control, and prophylaxis policies in livestock farms, to prevent spreading the virus throughout the region.

\section{MANUFACTURER}

${ }^{1}$ Instituto de Tecnologia do Paraná (Tecpar®). Curitiba, PR, Brazil.

Funding. Fundação de Amparo à Pesquisa do Estado do Acre (FAPAC).

Ethical approval. This study was approved by the Animal Use Ethics Committee of the Universidade Federal do Acre, Rio Branco campus, under the license number 64/2015.

Declaration of interest. The authors report no conflicts of interest. The authors alone are responsible for the content and writing of paper.

\section{REFERENCES}

1 Abreu V.L.V., Modena C.M., Silva J.A., Moreira E.C. \& Figueiredo M.M.N. 1990. Prevalência da leucose enzoótica bovina nos estados de Rondônia e Acre. Arquivo Brasileiro de Medicina Veterinária e Zootecnia. 42: 203-210.

2 Acre. Governo do Estado do Acre. 2016. Portal de Informações: Sobre o Acre. Available from: <http://www.ac.gov. br/wps/portal/acre/Acre/home>. [Accessed online in December 2018].

3 Akagami M., Oya S., Kashima Y., Seki S., Ouchi Y. \& Hayama Y. 2019. A hematologic key for bovine leukemia virus screening in Japanese black cattle. Journal of Veterinary Diagnostic Investigation. 31(4):568-571. doi: $10.1177 / 1040638719848449$.

4 Benitez-Rojas O.J., Roberts J.N., Norby B., Bartlett P.C., Maeroff J.E. \& Grooms D.L. 2019. Lack of Bovine leukemia virus transmission during natural breeding of cattle. Theriogenology. 126: 187-190.

5 Birgel Junior E.H., Dias W.M., Souza R.M., Pogliani F.C., Birgel D.B. \& Birgel E.H. 2006. Prevalência da infecção pelo vírus da leucose dos bovinos em animais da raça Simental, criados no estado de São Paulo. Ars Veterinaria. 22: 122-129.

6 Carneiro P.A.M., Araujo W.P., Birgel E.H. \& Souza K.W. 2003. Prevalência da infecção pelo vírus da leucose enzoótica dos bovinos e rebanhos leiteiros criados no Estado do Amazonas. Acta Amazonica. 33: 111-125.

7 Dohoo I.R., Martin S.W. \& Stryhn H. 2009. Veterinary Epidemiologic Research. 2nd edn. Charlottetown: VER Inc., 865 .

8 Farias M.V.N., Souza F.N., Lendez P.A., Martínez-Cuesta L., Santos K.R., Della Libera A.M.M.P., Ceriani M.C. \& Dolcini G.L. 2018. Lymphocyte proliferation and apoptosis of lymphocyte subpopulations in bovine leukemia virusinfected dairy cows with high and low proviral load. Veterinary Immunology and Immunopathology. 206: 41-48. 
9 Fernandes C.H.C., Melo L.E.H., Tenório T.G.S., Mendes E.I., Fernandes A.C.C., Ramalho T.R.R., Sobrinho P.A.M. \& Mota R.A. 2009. Soroprevalência e fatores de risco da infecção pelo vírus da leucose dos bovinos em rebanhos leiteiros da região norte do estado do Tocantins, Brasil. Arquivos do Instituto Biológico. 76: 327-334.

10 Frie M.C. \& Coussens P.M. 2015. Bovine leukemia virus: A major silent threat to proper immune responses in cattle. Veterinary Immunology and Immunopathology. 163(3): 103-114.

11 Frie M.C., Sporer K.R., Wallace J.C., Maes R.K., Sordillo L.M., Bartlett P.C. \& Coussens P.M. 2016. Reduced humoral immunity and atypical cell-mediated immunity in response to vaccination in cows naturally infected with bovine leukemia virus. Veterinary Immunology and Immunopathology. 182: 125-135.

12 Instituto Brasileiro de Geografia e Estatística (IBGE). 2017. Unidades da Federação. Available from: <http://www. ibge.gov.br/estadosat/perfil.php?> [Accessed online in January 2019].

13 Juliano R.S., Fioravanti M.C.S., Brito W.M.E.D., Abreu U.G.P. \& Souza S.N. 2014. Soroepidemiologia da leucemia bovina em bovinos curraleiros dos estados de Goiás e Tocantins, Brasil. Ciência Animal Brasileira. 15(3): 289-295.

14 Khudhair Y.I., Hasso S.A., Yaseen N.Y. \& Al-Shammari A.M. 2016. Serological and molecular detection of bovine leukemia virus in cattle in Iraq. Emerging Microbes \& Infections. 5(6): 1-6.

15 Kobayashi T., Inagaki Y., Ohnuki N., Sato R., Murakami S. \& Imakawa K. 2019. Increasing Bovine leukemia virus (BLV) proviral load is a risk factor for progression of Enzootic bovine leucosis: A prospective study in Japan. Preventive Veterinary Medicine. doi: 10.1016/j.prevetmed.2019.04.009. [Epub ahead of print].

16 Kohara J., Takeuchi M., Hirano Y., Sakurai Y. \& Takahashi T. 2018. Vector control efficacy of fly nets on preventing bovine leukemia virus transmission. Journal of Veterinary Medical Science. 80(10): 1524-1527.

17 Konishi M., Ishizaki H., Kameyama K., Murakami K. \& Yamamoto T. 2018. The effectiveness of colostral antibodies for preventing bovine leukemia virus (BLV) infection in vitro. BMC Veterinary Research. 14(419): 1-9.

18 Kuczewski A., Hogeveen H., Orsel K., Wolf R., Thompson J., Spackman E. \& Van Der Meer F. 2019. Economic evaluation of 4 bovine leukemia virus control strategies for Alberta dairy farms. Journal of Dairy Science. 102(3): 1-15.

19 Lojkić I., Balić D., Rudan N., Kovačić M., Čač Z., Periškić M., Bedeković T., Roić B. \& Grozdanić I.C. 2013. Eradication of bovine leukosis virus on a dairy farm through improved virus detection. Veterinarski Arhiv. 83(6): 581591.

20 Mendes E.I., Melo L.E.H., Tenório T.G.S., Sá L.M., Souto R.J.C., Fernandes A.C.C., Sandes H.M.M. \& Silva T.I.B. 2011. Intercorrência entre leucose enzoótica e tuberculose em bovinos leiteiros do estado de Pernambuco. Arquivos do Instituto Biológico. 78(1): 1-8.

21 Miller J.M. \& Van Der Maaten M.J. 1975. Serological detection of bovine leukemia virus infection. In: Proceedings of the 2nd CEC Seminar on Bovine Leukosis (Copenhagen, Denmark). 1 CD ROM.

22 Modena C.M., Abreu V.L.V., Silva J.A., Moreira E.C., Azevedo N.A. \& Rehfeld O.A.M. 1983. Ocorrência de infecção pelo vírus da leucose enzoótica bovina em animais importados. Arquivo Brasileiro de Medicina Veterinária e Zootecnia. 35(4): 565-573.

23 Molnár E., Molnár L., Dias H.T., Silva O.M. \& Vale W.G. 1999. Ocorrência da leucose enzoótica dos bovinos no estado do Pará, Brasil. Pesquisa Veterinária Brasileira. 19: 7-11.

24 Nekouei O., Vanleeuwen J., Sanchez J., Kelton D., Tiwari A. \& Keef G. 2015. Herd-level risk factors for infection with bovine leukemia virus in Canadian dairy herds. Preventive Veterinary Medicine. 119: 105-113.

25 Nishimori A., Konnai S., Okagawa T., Maekawa N., Goto S., Ikebuchi R., Nakahara A., Chiba Y., Ikeda M., Murata S. \& Ohashi K. 2017. Identification of an atypical enzootic bovine leukosis in japan by using a novel classification of bovine leukemia based on immunophenotypic analysis. Clinical and Vaccine Immunology. 24(9): 1-14.

26 Ochirkhuu N., Konnai S., Odbileg R., Nishimori A., Okagawa T., Murata S. \& Ohashi K. 2016. Detection of bovine leukemia virus and identification of its genotype in Mongolian cattle. Archives of Virology. 161(4): 985-991.

27 Ohno A., Takeshima S.N., Matsumoto Y. \& Ainda Y. 2015. Risk factors associated with increased bovine leukemia virus proviralload in infected cattle in Japan from 2012 to 2014. Virus Research. 210: 283-290.

28 Organização Mundial de Saúde Animal (OIE). 2012. Código terrestre de saúde animal. Leucose Enzoótica Bovina. Available from: <http://www.oie.int> [Accessed online in January 2019].

29 Ott S.L., Johnson R. \& Wells S.J. 2003. Association between bovine leukosis virus seroprevalence and herd-level productivity on US dairy farms. Preventive Veterinary Medicine. 61(4): 249-262. 
30 Panei C.J., Larsen A.E., Fuentealba N.A., Metz G.E., Echeverría M.G., Galosi C.M. \& Valera A.R. 2019. Study of horn flies as vectors of bovine leukemia virus. Open Veterinary Journal. 9(1): 33-37.

31 Pereira A.L.M., Costa A.F., Veschi J.L.A. \& Almeida K.S. 2013. Soroprevalência da leucose enzoótica bovina - revisão de literatura. Revista Científica Eletrônica de Medicina Veterinária. 11(21): 1-20.

32 Polat M., Takeshima S. \& Aida Y. 2017. Epidemiology and genetic diversity of bovine leukemia vírus. Virology Journal. 14(209): 1-16.

33 Rajão D.S. 2008. Efeito da infecção pelo vírus da leucose enzoótica bovina na produção de leite e reprodução de rebanhos leiteiros. 26f. Dissertação (Mestrado em Ciência Animal) - Universidade Federal de Minas Gerais, Escola de Veterinária, Belo Horizonte.

34 Ruiz V., Porta N.G., Lomónaco M., Trono K. \& Alvarez I. 2018. Bovine leukemia virus infection in neonatal calves. Risk factors and control measures. Frontiers in Veterinary Science. 5: 1-7.

35 Santos G.R., Oliveira J.M.B., Brandespim D.F., Oliveira A.A.F., Mota R.A. \& Pinheiro Júnior J.W. 2013. Análise epidemiológica da infecção pelo vírus da leucose enzoótica bovina (LEB), na microrregião Garanhuns, Pernambuco, Brasil. Revista Brasileira de Medicina Veterinária. 35(4): 371-377.

36 Santos H.P., Pereira H.M., Nascimento S.A., Coutinho L.C.A., Teixeira W.C., Arruda R.C.N., Bezerra N.P.C., Bezerra D.C. \& Castro R.S. 2011. Frequência de anticorpos e fatores de risco associados à leucose enzoótica bovina em rebanhos da bacia leiteira do estado do Maranhão. Arquivos do Instituto Biológico. 78(3): 351-358.

37 Şevik M., Avcı O. \& İnce O.B. 2015. An 8-year longitudinal sero-epidemiological study of bovine leukaemia virus (BLV) infection in dairy cattle in Turkey and analysis of risk factors associated with BLV seropositivity. Tropical Animal Health and Production. 47: 715-720.

38 Shettigara P.T., Samagh B.S. \& Lobinowich E.M. 1986. Eradication of bovine leukemia virus infection in commercial dairy herds using the agar gel immunodiffusion test. Canadian Journal of Veterinary Research. 50: 221-226.

39 Sun W.W., Lv W.F., Cong W., Meng Q.F., Wang C.F., Shan X.F. \& Qian A.D. 2015. Mycobacterium avium subspecies paratuberculosis and bovine leukemia virus seroprevalence and associated risk factors in commercial dairy and beef cattle in northern and northeastern China. BioMed Research International. 1: 1-7.

40 Tsutsui T., Kobayashi S., Hayama Y. \& Yamamoto T. 2016. Fraction of bovine leukemia virus-infected dairy cattle developing enzootic bovine leukosis. Preventive Veterinary Medicine. 124: 96-101. 